\title{
The Role of Land Wealth on Child Labour in Vietnam
}

\author{
Yin Li Toh ${ }^{1}$
}

Published online: 7 June 2018

(C) The Author(s) 2018

JEL $\mathbf{J} 21 \cdot \mathrm{O} 10$

The economics literature generally considers income poverty to be the main cause of child labour. However, recent papers have cast doubt on this, showing evidence that greater land wealth leads to higher child labour. Bhalotra and Heady (World Bank Economic Review, 2003) showed that land size has a positive effect on child labour in Ghana and Pakistan. Supporting evidence has also been found in Burkina Faso (Dumas, Oxford Economic Papers, 2007).

Land in agrarian societies is considered a source of wealth and thus, this effect is labeled as the wealth paradox. Basu et al., (Journal of Development Economics, 2010) considered labour market imperfections in their theoretical model, and suggested an inverse- $U$ shaped relationship between land size and child labour. It is argued that labour market imperfections are significant enough to hinder the expected negative relationship between household wealth and child labour.

This wealth paradox has motivated research studying the impact of household-owned land on child labour in Vietnam, as research on this area in Southeast Asia is scarce. In the context from Vietnam, many papers using data from the 1990s find an association between poverty and child labour. Edmonds (The Journal of Human Resources, 2005) reported that per capita expenditure increases across households that moved out of poverty can explain up to $80 \%$ of the decline in child labour. Additionally, increases in rice prices during the 1990s through trade liberalisation caused nearly half of the child labour decline in Vietnam (Edmonds and Pavcnik, Journal of International Economics, 2004).

Even though empirical evidence supports the poverty hypothesis for child labour in Vietnam, this paper hypothesizes that the wealth paradox of child labour is present in Vietnam post-1993. Vietnam introduced the 1993 Land Law that redistributed land rights, and subsequently allowed households to own land as assets and stored wealth. Could the

Yin Li Toh

y.1.toh@warwickgrad.net

1 University of Warwick, Coventry CV4 7AL, UK 
increase in land holdings signal productive employment opportunities and higher child labour incidence? Since children's labor in Vietnam is mostly agricultural work, this research questions whether substitution effects of land ownership are large enough to increase child labour in Vietnam in the 2000s.

The data used in this study come from the Young Lives panel survey conducted by Oxford University's Young Lives project. Using the older cohort data between 2002 and 2009, the effect of land wealth on child labour in Vietnam is studied following the framework of (Basu, et al., Journal of Development Economics, 2010). A non-binary child labour variable included time spent in domestic work. It is argued that through this channel, households substitute adult labour for child labour as a response to labour market imperfections.

Since $24.9 \%$ of the children in the dataset do not work, a Tobit model is employed to address the zero dependent variable values. The Tobit model estimates support the hypothesis of an inverted-U shaped relationship between land and child labour. Per capita consumption expenditure is significant and has the expected negative effect on child labour.

The effect of land on the probability of work is larger for males compared to females, while the corresponding effect for hours of work is larger for females. As land is a proxy for marginal child labour productivity, females can be seen as less productive and are less of a perfect substitute for labour than males. Females also work longer hours compared to males in the presence of pre-school age children (below age 6). This suggests that pre-school age children are net costs to domestic resources. Human capital for females can be judged as less valuable than for males.

Further, the main model Tobit estimation results hold for an alternative measure of agrarian wealth. The land variable in the main model is replaced using number of cattle. Not only does it require a smaller investment for agrarian households, cattle ownership is a reasonable measure of stored wealth to cope with income shocks.

Empirical results confirm the presence of the wealth paradox in Vietnam, in which asset-ownership is a concern for increasing child labour. Policymakers in Vietnam are urged to reconsider poverty alleviation programs, such as the 1993 Land Law that allowed for redistribution and income transfers. In Vietnam where labour standards do not yet cover family business and farming, effective child labour regulations need to consider how agrarian households cope with labour market imperfections. The inclusion of domestic work has revealed the channel through which the wealth paradox is explained by labour market imperfections.

Despite the apparently satisfactory Tobit estimation results, diagnostic tests reveal nonnormality and heteroskedasticity. Future research should consider the censored least absolute deviations model for more consistent estimations. This research should also be extended to study the impact of land wealth on schooling, as child labour may have harmful effects on human capital development. (Basu, Journal of Development Economics, 1999).

Acknowledgements I would like to thank my tutor, Stefania Paredes Fuentes for her academic supervision, encouragement and constructive feedback throughout the development of this research at the University of Warwick. I am also grateful to Ranjan Ray of Monash University, Australia who introduced to me the theoretical and empirical field of child labour.

Open Access This article is distributed under the terms of the Creative Commons Attribution 4.0 International License (http://creativecommons.org/licenses/by/4.0/), which permits unrestricted use, distribution, and reproduction in any medium, provided you give appropriate credit to the original author(s) and the source, provide a link to the Creative Commons license, and indicate if changes were made. 